\title{
Knowledge, Attitude and Practices of Mothers Regarding Exclusive Breastfeeding in Infants Admitted in PIMS, Islamabad
}

\author{
Sana Majeed ${ }^{1 *}$, Abdul Momin Rizwan Ahmed ${ }^{1}$, Farah Naeem ${ }^{1}$, Sumaira $\mathrm{Naz}^{2}$ \\ ${ }^{1}$ Tertiary Care Hospital PIMS Islamabad Pakistan, University of Lahore Islamabad Campus, Shifa College of Nursing Islamabad, Pakistan \\ ${ }^{2}$ Vice Principal, Institute of Nursing Wah Medical College, Rawalpindi, Punjab, Pakistan
}

DOI: $10.36348 /$ sjnhc.2020.v03i02.002 $\quad$ | Received: 21.01 .2020 | Accepted: 28.01.2020 | Published: 12.02 .2020

*Corresponding author: Sana Majeed

Abstract

Objective: To assess the knowledge, attitudes and practices of mothers regarding exclusive breastfeeding in infants, admitted in PIMS, Islamabad. Study Design: Descriptive qualitative study design based on in-depth interviews. Place and Study Duration: It was carried out from December 2015 to May 2016 involving mothers of infants admitted in PIMS Islamabad. Materials and Methods: Data was collected through in-depth interviews from the mothers of infants till the saturation of ideas, which was came at the thirtieth respondent. The collected data was analyzed manually. Verbatim notes were taken and interviews were recorded. After transcribing the data, nodes and sub-nodes were developed and on the basis of them, themes were generated. Results: The results of the study showed that most of the mothers knew the advantages of breast feeding and its importance for the health of the infants. The main reason behind this was the cultural practices, running in the families for years as well as the myths of elderly at homes, who were the main decision makers. Conclusion: The study gave a basic level of knowledge, attitude and practices of mothers about exclusive breast feeding. Breastfeeding is a natural and beneficial source of nutrition and provides the healthiest start for an infant.

Keywords: Breastfeeding, Knowledge, Attitude, Practices, Infants, Mothers.

\begin{abstract}
Copyright @ 2020: This is an open-access article distributed under the terms of the Creative Commons Attribution license which permits unrestricted use, distribution, and reproduction in any medium for non-commercial use (NonCommercial, or CC-BY-NC) provided the original author and source are credited.
\end{abstract}

\section{INTRODUCTION}

Exclusive breastfeeding means that the infant only receives breast milk with no addition of liquids or solids and not even water until six months of age. It is an ideal food for the infant. Additionally, it is also beneficial for the health of the mothers. Evidence has shown that on a community level, exclusive breastfeeding is optimal feeding for the infants for the first six months. Thereafter, complementary feeding should be added to breastfeeding from six months and continued up to two years of age or beyond [1].

Breast milk contains all the nutrients and minerals and hence, the infant does not require any other food or fluids other than breast milk [1].

WHO also states that infants should receive only breast milk from birth to six months of age. It has better outcome for the neonates. Exclusive breastfeeding reduces the mortality and morbidity rates in the initial months of life. Mothers need counseling and support regarding practices of exclusive breastfeeding during postnatal care. Studies have shown that it has great influence on the health of the mother as well as infant. Breast milk is easily digestible for the infant.

It protects the infant from gastrointestinal infections. It is recommended that exclusive breastfeeding should be initiated within first hour of birth. It releases oxytocin that protects the mother from post-partum hemorrhage. Thus, it reduces the risk of newborn and maternal mortality rates [2].

Breast milk is a rich source of energy. It fulfills the demand of growing child especially in the age of six to twenty-three months. It can provide critical source of energy and nutrients even in the time of illness and disease. It provides a way to recovery from illness. Breast milk is a way of survival for the babies who are malnourished, preterm and low birth weight infants. Therefore, breast milk reduces the risk of morbidity and mortality [2].

Breast feeding is - cost effective. It is a best way of reducing health costs at individual, family, community level as well as at national level by 
providing protection against infections especially diarrhea and pneumonia and reducing mortality rates. Thus, breast feeding reduces the economic costs [2].

Breastfed infants have a less chance to become overweight and obese as compared to non-breastfed infants. Studies have shown that breastfed infants have better intellectual levels than non-breastfed infants. They grow well and are more active and are more energetic than non-breastfed infants. Breastfed infants have sharp mind, good vision and better developmental outcomes later in life. Breastfeeding also provides protection to mothers. It protects the mother from breast and ovarian cancers. Hormonal changes occur due to breastfeeding of infants in first six months of age. It induces lack of menstruation. This is also a natural method of birth control called lactation amenorrhea method (LAM) [2].

Breast milk is the best food for the growth and development of the infants. It contains all the vitamins, minerals and antibodies also contain enzymes for the infant's survival. It has a potential to reduce twelve percent deaths in children [3].

Exclusive breastfed infants have a less chance to get diarrhea, pneumonia and other infectious diseases than non-breastfed infants. Their quality of life is better and longer. Breast milk is safe; it has right temperature, there is no need to adjust temperature of breastfeed and infant can take it easily. It requires no preparation like boiling, cooling and mixing as artificial or bottle milk requires. It is the best sterile feed for the infants with no germs and infections [4].

Breastfeeding is a cost effective and affordable method. It requires no money and physical resources. It is affordable even for the poor. It is easily accessible, reliable and available in sufficient quantity for the infants. In this way, breastfeeding allows infants to grow and develop to their full potential [4].

Breastfeeding reduces deaths as it provides protection against respiratory tract infections, diarrhea and pneumonia the major child killer in the world. Infants who are breastfed have fourteen times more chance of survival than non-breastfed infants [4].

Breastfeeding is the best start of the child. There is no replacement of breast feed for the infants. It contains all the nutrients and energy which the infants require for their growth and survival. It is rich in minerals, all vitamins, sugar, water, fat, proteins and especially rich in antibodies like $\operatorname{IgA}$ and $\operatorname{IgG}$ that promotes the infant's survival [4].

First milk that is colostrum contains the main immune factor $\operatorname{IgA}$ that is present in rich amount in colostrum. IgA protects the infants against germs especially in the intestines, nose and throat. Certain studies have shown that breast feed also provides protection against certain childhood cancers [4].

The American Academy of Pediatrics states that breastfeeding is the best way of preventing from sudden infant death syndrome (SIDS). Breastfeeding is also beneficial for mothers. It is helpful in loosening weight of pregnancy. Breastfeeding help uterus to return to its normal size and weight. It has been shown to reduce the risk of osteoporosis. Breast feeding is the best way that makes a bond between baby and mother [5].

\section{MATERIALS AND METHODS}

This was a descriptive qualitative study based on in-depth interviews lasted from December 2015 May 2016. The study was done in the Pakistan Institute of Medical Sciences, PIMS, Islamabad, which is one of the tertiary care hospitals involving mothers of infants admitted in PIMS, Islamabad. Mothers of infants having birth defects like cleft lip and palate, neurodegenerative brain diseases \& severe birth asphyxia or infants with other special needs were excluded from the study. The data collection was continued till the saturation of ideas, which was came at the thirtieth respondent. The collected data was analyzed manually. Verbatim notes were taken and interviews were recorded. After transcribing the data, nodes and sub-nodes were developed and on the basis of them, themes were generated.

The approval of the study was taken from the IRB of the Institute of Health \& Management Sciences, Islamabad. Informed written consent was taken from the mothers of infants and proper explanation was given to the participants. Confidentiality of the data collected was ensured to the participants. The names and identities of the participants were kept confidential.

\section{RESULT}

This study helped us to identify the knowledge, attitude and practices of mothers regarding exclusive breastfeeding and factors that may affect breastfeeding practices in the study population. Mothers of infants admitted in Children Hospital, Pakistan Institute of Medical Sciences, Islamabad were included in the study. 
Table-1: Meaning of exclusive breastfeeding

\begin{tabular}{|c|c|c|c|}
\hline NODES & SUB NODES & & THEMES \\
\hline $\begin{array}{l}\text { 1-Meaning of } \\
\text { Exclusive } \\
\text { Breastfeeding }\end{array}$ & $\begin{array}{l}\text { - She could understand the meaning of EBF and } \\
\text { she said that EBF is important for the infant and } \\
\text { EBF protects the infant from various diseases. } \\
\text { - Only mother's milk without addition of foods } \\
\text { and fluids with it. } \\
\text { - Giving mother milk till } 4 \text { months } \\
\text { - Every infant must receive only mother's milk } \\
\text { till } 6 \text { months of age } \\
\text { - Give breastfeed until } 2 \text { years of age }\end{array}$ & $\begin{array}{l}+++ \\
++ \\
++ \\
+ \\
+ \\
+\end{array}$ & $\begin{array}{l}\text { Exact meaning of exclusive } \\
\text { breastfeeding was unknown to } \\
\text { most but they considered it } \\
\text { something important for the } \\
\text { infant }\end{array}$ \\
\hline
\end{tabular}

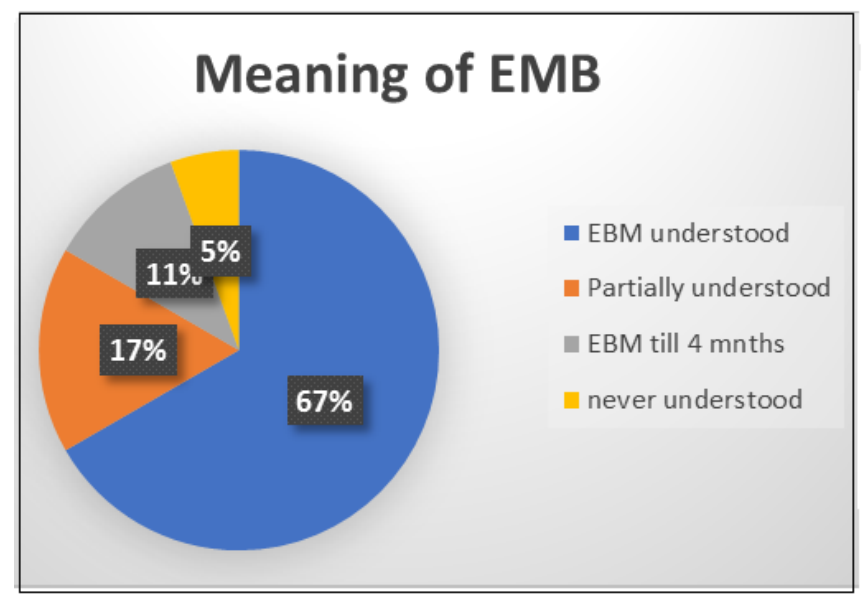

Fig-1: Meaning of EBM

When asked about the meaning of exclusive breastfeeding, respondents provided information about its meaning. Breastfeeding They could understand the meaning of exclusive breastfeeding but the exact meaning was unknown. All of the respondents considered it important for the infants. Decisions were made in the best interest of the mothers. One of the mothers stated, "Breastfeeding is very much important for the growth and development of the infant. It protects the infant from various diseases." It has been showed that the knowledge of mothers regarding exclusive breastfeeding was good and satisfactory.

Table-2: Difference between breastfeeding and exclusive breastfeeding

\begin{tabular}{|c|c|c|c|}
\hline NODES & SUB NODES & & THEMES \\
\hline $\begin{array}{l}2-\quad \text { Difference between } \\
\text { breastfeeding and exclusive } \\
\text { breastfeeding }\end{array}$ & $\begin{array}{l}\text { - Breastfeeding continues till } 2 \text { years of } \\
\text { age while Exclusive Breastfeeding stops } \\
\text { at } 6 \text { months of age } \\
\text { - Give breastfeed for } 2.5 \text { years and do not } \\
\text { know about EBF } \\
\text { Breastfeeding is important for infant but } \\
\text { don't know about EBF }\end{array}$ & $\begin{array}{l}+++ \\
++\end{array}$ & $\begin{array}{l}\text { Some mothers knew the } \\
\text { difference while some } \\
\text { had no idea }\end{array}$ \\
\hline
\end{tabular}

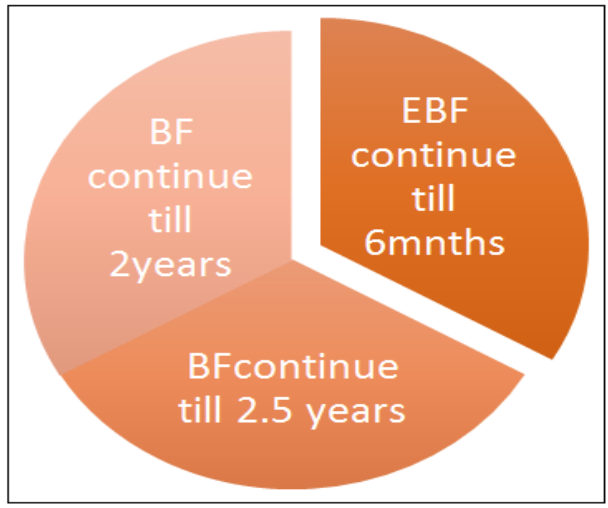

Fig-2: Difference between BF and EBF 
Majority of the mothers knew the difference between breastfeeding and exclusive breastfeeding. However, some of the mothers had no idea about the difference between the two. It was also observed that the mothers mostly followed the advice of the elders in this regard and also added "ghutti" or others food items with exclusive breastfeeding. This study showed that few respondents did not know the difference between breastfeeding and exclusive breastfeeding.

Table-3: Importance of exclusive breastfeeding

\begin{tabular}{|l|c|l|l|}
\hline NODES & SUB NODES & THEMES \\
\hline 3-Importance of EBF & $\begin{array}{l}\text { Necessary for first } 6 \text { months and it is } \\
\text { very much important for the infants; } \\
\text { there is no replacement of mother milk } \\
\begin{array}{l}\text { It is important and should be continued } \\
\text { for 2 years }\end{array}\end{array}$ & + & $\begin{array}{l}\text { Majority of the mothers } \\
\text { knew the importance of } \\
\text { EBF }\end{array}$ \\
\hline
\end{tabular}

All of the respondents agreed that exclusive breastfeeding is important for the infants. One of them replied, "It is very much necessary and there is no replacement of mother milk. It contains all the nutrients and minerals for the growth and development of the infant especially during first six months of age."
This study clearly showed that mothers knew that exclusive breastfeeding is necessary for the health of the infants.

Table-4: Meaning of colostrum and should it be given to infants or not

\begin{tabular}{|c|c|c|c|}
\hline NODES & SUB NODES & & THEMES \\
\hline $\begin{array}{l}\text { 4- Meaning of colostrum } \\
\text { and should it be given to } \\
\text { infants or not }\end{array}$ & $\begin{array}{l}\text { - It is } 1^{\text {st }} \text { yellowish milk, } \\
\text { given to the infant } \\
\text { - } 1^{\text {st }} \text { milk but don't give it } \\
\text { to the infants } \\
\text { - Waste it } \\
\text { - } \quad \text { Give it to the infant }\end{array}$ & $\begin{array}{l}+++ \\
++ \\
+++ \\
++\end{array}$ & $\begin{array}{l}\text { Most mothers were against colostrum } \\
\text { because of misconception and tradition } \\
\text { they follow and education they get from } \\
\text { their elders }\end{array}$ \\
\hline
\end{tabular}

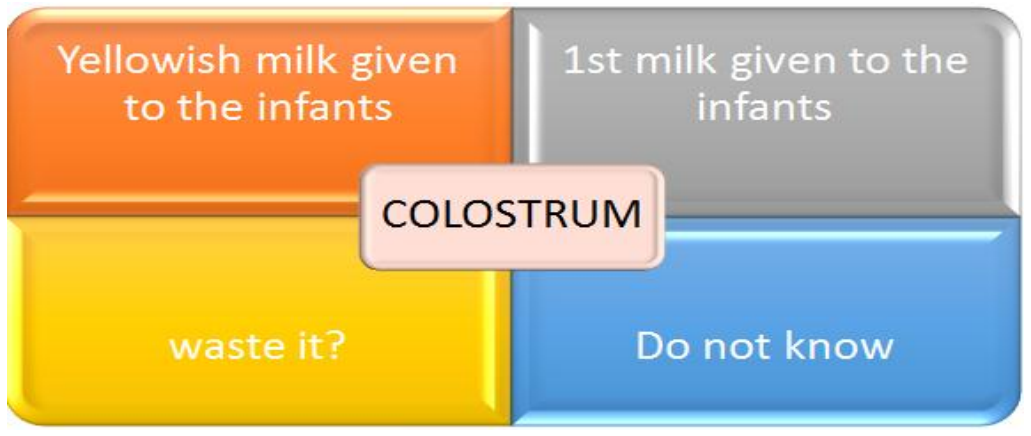

Fig-3: Meaning of colostrum

It showed that majority of the mothers knew the meaning of colostrum. As one of the participants stated, "Colostrum is the first yellowish milk comes from mother's milk." But majority of the mothers did not know the benefits of colostrum. They thought that it was harmful so that wasted it. Most of them did not know the fact and believed to be wasted it. There had been lots of issues. They followed the traditions and instructions of their elders. There had been misconception and lack of education.

Table-5: What happened if infant is not exclusive breastfed

\begin{tabular}{|l|l|l|l|}
\hline NODES & SUBNODES & & THEMES \\
\hline $\begin{array}{l}\text { 5- If infant is } \\
\text { not exclusively } \\
\text { breastfed }\end{array}$ & $\begin{array}{l}\text { Nothing happens } \\
\text { If not exclusively breastfed, then he will } \\
\text { become sick and suffer from many diseases } \\
\text { especially GI problems and chest problems, } \\
\text { bones and teeth will become weak, he will not } \\
\text { be active, immune system will not fully } \\
\text { develop } \\
\text { They cannot grow well }\end{array}$ & ++++++ & $\begin{array}{l}\text { Majority } \\
\text { know that if infant is not } \\
\text { exclusively breastfed he } \\
\text { will suffer from many } \\
\text { diseases and cannot grow } \\
\text { well }\end{array}$ \\
\hline
\end{tabular}




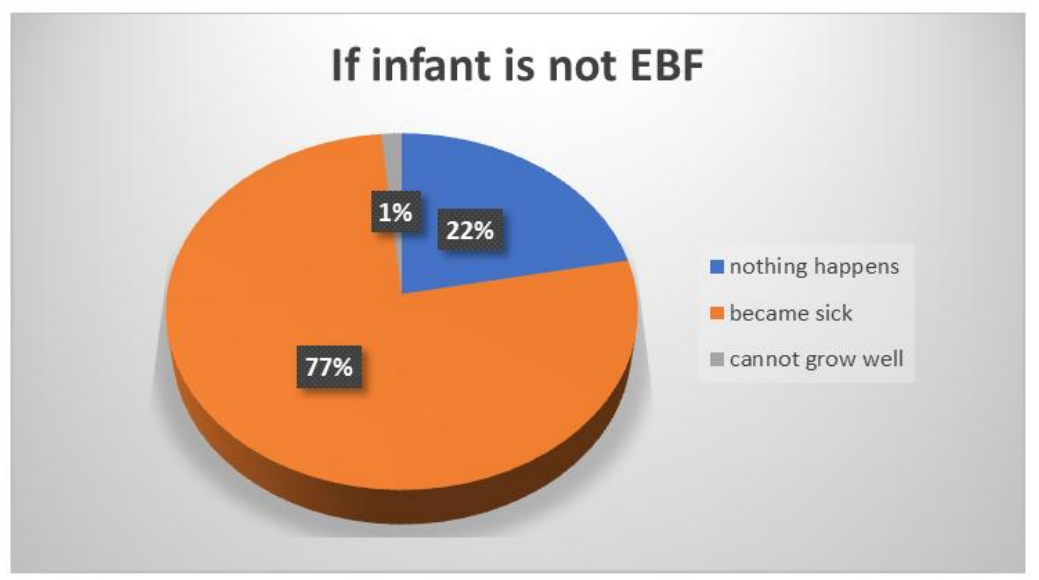

Fig-4

Exclusive breastfeeding has a strong connection with the growth and development of the infants. Different respondents explained in different ways and all of respondents knew that if infants were not exclusively breastfed, they then suffered from many diseases and could not grow well. One of the respondents described, "If the infant is not exclusively breastfed, he will soon become sick and suffer from many diseases especially GI problems, chest problems, bones and teeth will become weak. Infant will not be active." She further said, "Immune system will not fully develop and infant will not grow well."

Table-6: Meaning of complementary feed and time to initiate it

\begin{tabular}{|l|c|l|l|l|}
\hline NODES & SUB NODES & & THEMES \\
\hline $\begin{array}{l}\text { 6-Meaning of } \\
\text { complementary feed }\end{array}$ & $-\begin{array}{l}\text { It includes khichri, porridge, } \\
\text { mashed banana, mashed potato, } \\
\text { and time to initiate it }\end{array}$ & $\begin{array}{l}\text { custard etc. It starts from 6 months } \\
\end{array}$ & Starts from 5 months & $\begin{array}{l}\text { Almost all mothers had some } \\
\text { concept of CF but they didn't } \\
\text { know when to initiate it }\end{array}$ \\
& $\begin{array}{l}\text { - Starts from 4 months } \\
\text { - Starts from 3 months }\end{array}$ & ++ \\
\hline
\end{tabular}

Almost all of the mothers had some concept of complementary feeding but they did not know the exact time to initiate it. One of the mothers said, "Complementary feeding means semi-solid diet with breastfeeding." But majority of them did not know when complementary feeding started. Some of them said that it started after three months, some said from two or four months. Only few mothers knew the exact time to start complementary feeding. "Complementary feeding should start from six months." It has been shown that there is a significant gap regarding knowledge of mothers about complementary feeding.

Table-7: Duration of exclusive breastfeeding and why

\begin{tabular}{|l|c|l|l|}
\hline NODES & SUB NODES & & THEMES \\
\hline 7-Duration of & $\begin{array}{l}\text { EBF is continued till 6 months and if CF } \\
\text { EBF and why }\end{array}$ & $\begin{array}{l}\text { Starts before 6 months, infant will not } \\
\text { tolerate and digest it }\end{array}$ & \\
$\begin{array}{l}\text { Continue till 2-3mnths only } \\
\text { Don't know }\end{array}$ & $\begin{array}{l}\text { Most of the mothers had } \\
\text { knowledge regarding how long } \\
\text { EBF should be continued }\end{array}$ \\
\end{tabular}

Most of the mothers had knowledge regarding how long it should be continued. A respondent described, "Exclusive breastfeeding should be continued till six months of age and it must be given to the infant because if other foods and fluids add before six months the child will become sick and will has gastric and stomach problem as well as chest problems." This study revealed that strategies are mandatory to scale up the knowledge of mothers regarding exclusive breastfeeding, when to initiate and when it should be continued. 
Table-8: Exclusive breastfeeding and health of the infant

\begin{tabular}{|l|c|l|l|}
\hline NODES & SUB NODES & THEMES \\
\hline $\begin{array}{l}\text { 8-EBF and } \\
\text { overall health } \\
\text { of the infant }\end{array}$ & $\begin{array}{l}\text { It will improve the health of infant because } \\
\text { it will protect him from infection, diseases; } \\
\text { it has all nutrients and makes bones and } \\
\text { teeth strong } \\
\text { It will improve the health of the infant }\end{array}$ & +++++++ & $\begin{array}{l}\text { Most of the mothers gave } \\
\text { positive response that EBF } \\
\text { improves the health of the } \\
\text { infant }\end{array}$ \\
\hline
\end{tabular}

Exclusive breastfeeding is proportional to the health of the infant. It is a side chain of the growing infant. Most of the mothers gave positive response that exclusive breastfeeding improved the health of the infant. One of the participants said, "Exclusive breastfeeding protects the child from various infections and diseases. It has all the nutrients which make the child grow well." The study revealed that women generally have positive attitude regarding exclusive breastfeeding.

Table-9: Advantages and disadvantages of EBF

\begin{tabular}{|c|c|c|c|}
\hline NODES & SUB NODES & & THEMES \\
\hline $\begin{array}{lr}\text { 9-Advantages } & \text { and } \\
\text { disadvantages } & \text { of } \\
\text { EBF } & \end{array}$ & $\begin{array}{l}\text { - improve the health of infant, it protects him from } \\
\text { infection, diseases, it has all nutrients and makes } \\
\text { bones and teeth strong and no disadvantage } \\
\text { it also harmful for infant if mother has hepatitis B } \\
\text { and C } \\
\text { - Don't know because I'm worried that my infant is } \\
\text { sick }\end{array}$ & $\begin{array}{l}\text { ++++++ } \\
++ \\
+\end{array}$ & $\begin{array}{l}\text { They know the } \\
\text { advantages } \\
\text { EBF }\end{array}$ \\
\hline
\end{tabular}

Almost all of the participants knew the advantages of exclusive breastfeeding. One of the respondents said, "Exclusive breastfeeding is the source of curing forty diseases and protects the infant from them." Only a few of participants described that it has no disadvantages. The study results showed that by and large, mothers knew the advantages of exclusive breastfeeding and its importance for the infant.

Table-10: EBF is beneficial for mothers or not

\begin{tabular}{|c|c|c|c|}
\hline NODES & SUB NODES & & THEMES \\
\hline $\begin{array}{l}10-\mathrm{EBF}-\text { Beneficial } \\
\text { for mothers or not }\end{array}$ & $\begin{array}{l}\text { - Yes, it is very much beneficial for mothers, } \\
\text { it protects them from breast cancer } \\
\text { - It only benefits the infants } \\
\text { - Don't know } \\
\text { - Not beneficial for mothers }\end{array}$ & $\begin{array}{l}+++++ \\
+++ \\
+ \\
+\end{array}$ & $\begin{array}{l}\text { EBF will protect mothers } \\
\text { from breast cancer }\end{array}$ \\
\hline
\end{tabular}

Most of the participants knew that exclusive breastfeeding was also beneficial for mothers as well. One of the mothers described, "Exclusive breastfeeding also protects the mother from breast cancer."
Unfortunately, some of the mothers do have knowledge but still they ignored practicing and implementing. The study revealed that there is a need of strong implementation modalities.

Table-11: Importance of mother's education regarding EBF

\begin{tabular}{|l|c|l|l|}
\hline NODES & SUB NODES & & THEMES \\
\hline $\begin{array}{l}\text { 11-Importance of } \\
\text { mother's education } \\
\text { regarding EBF }\end{array}$ & $\begin{array}{l}\text { Education has no influence on practice of } \\
\text { EBF, our elders have no education but they } \\
\text { know better about EBF }\end{array}$ & $+\begin{array}{l}\text { Mothers' education is } \\
\text { important for practices } \\
\text { of EBF }\end{array}$ \\
& $\begin{array}{l}\text { Education has great influence, without } \\
\text { education we are nothing and it improves } \\
\text { the practices of EBF } \\
\text { Education has less influence }\end{array}$ & ++++++ & + \\
\hline
\end{tabular}

Education has great influence in every aspect of life. Especially mothers' education is necessary for the better development of their babies. Mothers' education influences very much on breastfeeding practices. Most of the participants knew that education was very important for practicing exclusive breastfeeding. They knew that without education we were nothing and if we were uneducated, we could not understand the term exclusive breastfeeding. Most of them described that it was an education that gave us awareness. 
Table-12: Difference b/w EBF infant and non-EBF infant

\begin{tabular}{|l|c|l|l|}
\hline NODES & SUB NODES & THEMES \\
\hline 12-Difference \\
b/w EBF infant \\
$\begin{array}{l}\text { and non-EBF } \\
\text { infant }\end{array}$ & $\begin{array}{l}\text { The infant who is not EBF becomes weak, } \\
\text { frequently ill, has problems of eyes, and if } \\
\text { breastfeed - will not suffer from diseases } \\
\text { frequently, he/she will be attracted more to } \\
\text { mother; infant will be stronger than others. } \\
\text { There is so much difference b/w them }\end{array}$ & ++++++ & $\begin{array}{l}\text { The one who is not } \\
\text { exclusively breastfed } \\
\text { is prone to many } \\
\text { diseases }\end{array}$ \\
\hline
\end{tabular}

Almost all of the participants knew the difference. The study revealed that majority of the participants knew the exact difference between them.

Table-13: Believe to give exclusive breast feed to your infant

\begin{tabular}{|l|c|l|l|}
\hline NODES & SUB NODES & THEMES \\
\hline $\begin{array}{l}\text { 13-Believe in EBF } \\
\text { your infant }\end{array}$ & $\begin{array}{l}\text { Believe to give EBF to their } \\
\text { infant }\end{array}$ & $\begin{array}{l}+++++++++ \\
\text { Positive response and mothers } \\
\text { agree to give EBF }\end{array}$ \\
\hline
\end{tabular}
infants.

All of the participants showed positive response and they were willing to give exclusive breast feed to their

Table-14: Difficult to give exclusive breastfeed to your infant at night

\begin{tabular}{|l|c|l|l|}
\hline NODES & SUB NODES & THEMES \\
\hline $\begin{array}{l}\text { 14-Difficult to EBF } \\
\text { your infant at night }\end{array}$ & $\begin{array}{l}\text { It is not difficult because bottle milk is difficult to } \\
\text { make, there is problem of maintaining temperature } \\
\text { of bottle milk }\end{array}$ & +++++ & $\begin{array}{l}\text { It is not difficult to } \\
\text { give EBF at night }\end{array}$ \\
& $\begin{array}{l}\text { It is difficult but need of the infant } \\
\text { - Not difficult } \\
\text { - Don't know }\end{array}$ & + \\
\end{tabular}

Most of the mother described that it was difficult to give breastfeed at night but they knew that it was beneficial for the health and development of the infant. One of the respondents replied, "It is not difficult to give exclusive breast feed to infant at night but it is difficult to prepare bottle feed at night. There are issues of maintaining temperature cleanliness." The study results showed that mothers gave priority and importance to exclusive breastfeed.

Table-15: Type of diet you give to your infant

\begin{tabular}{|l|c|l|l|}
\hline NODES & SUB NODES & \multicolumn{1}{|l|}{ THEMES } \\
\hline $\begin{array}{l}\text { 15-Type of diet you } \\
\text { give to your infant }\end{array}$ & $\begin{array}{l}\text { Yolk, Cerelac, banana, porridge, } \\
\text { khichri with breast milk }\end{array}$ & $\begin{array}{l}++++ \\
\text { Only breastfeed }\end{array}$ & $\begin{array}{l}\text { Some mothers gave EBF while some } \\
\text { gave semi-solids according to the age of } \\
\text { the infant }\end{array}$ \\
& $\begin{array}{l}++++ \\
+\end{array}$ & \\
\hline
\end{tabular}

Mothers knew that which type of food they could gave to their infants. Some mothers were giving only breastfeeding, some all solid or semi-solid diet to their infants. They were giving diet according to the age of the infants. One of the respondents said, "I am giving banana, Cerelac and egg yolk including breast milk to my baby."

Table-16: Importance of family planning

\begin{tabular}{|c|c|c|c|}
\hline NODES & SUB NODES & & THEMES \\
\hline $\begin{array}{l}\text { 16-Importance of } \\
\text { family planning }\end{array}$ & $\begin{array}{l}\text { - } 3-5 \text { years gap is necessary otherwise it will } \\
\text { affect the health of infant as well as mother } \\
\text { - } 2 \text { years gap is must } \\
\text { - } \quad \text { Family planning is important, it will improve } \\
\text { the health of the mother and children } \\
\text { - FP is important because mother will breastfeed } \\
\text { her child properly and for complete } 2 \text { years }\end{array}$ & $\begin{array}{l}+ \\
+ \\
++++ \\
+++\end{array}$ & $\begin{array}{l}\text { Almost all of the mothers } \\
\text { knew the importance of } \\
\text { Family Planning }\end{array}$ \\
\hline
\end{tabular}


Family planning is important for the health of the infant as well as mother. Almost all of the mothers knew the importance of family planning. One of the participants stated, "Family planning is important and two years gap is must for the better nourishment of the child."

In a nutshell we can say that there is need of intensified focus on the training of mothers regarding exclusive breastfeeding. It is mandatory to develop more competencies and to fill the gap. Service structure is required to deal with the issues.

\section{DISCUSSION}

Pakistan is one of the countries in South Asia to focus on exclusive breast feeding with the vision of improving the health of the infant as well as mother. Despite the efforts put in by the government, we are still not able to reduce the infant mortality rate to a considerable level. Pakistan is lagging far behind in effective implementation for practices of exclusive breastfeeding.

Findings of our study identified the health system related issues that there was a gap between knowledge and practices of mothers regarding exclusive breastfeeding. There is a need to improve the practices of mothers regarding exclusive breastfeeding and scale up the knowledge of mothers regarding exclusive breastfeeding by strong implementation modalities in health care units.

WHO and UNICEF recommend that breastfeeding should be initiated within one hour of birth and exclusive breastfeeding should be continued till six months and complementary feeding should be started after six months. Breast feeding is so important because it could save the lives of 800,000 children every year. Breast feeding and complementary feeding are beneficial because these can prevent about lives of 220,000 children in countries where stunting is prevalent [2]. All of the participants in our study could understand the meaning of exclusive breastfeeding and they knew that exclusive breastfeeding was important for the life of the infant. But still there is a gap in the knowledge of mothers regarding exclusive breastfeeding. All of the mothers knew the advantages of exclusive breastfeeding but they did not know the exact time to initiate exclusive breastfeeding and when to start complementary feeding. There is a need to increase the knowledge of mothers regarding exclusive breastfeeding through media and by training of lady health workers to visit the community on regular basis and teach them about exclusive breastfeeding. Pregnant mothers should be given education and guidelines regarding exclusive breastfeeding during their antenatal visits.
Breastfeeding has long term impact on childhood development and cognition. Breastfeeding not only promotes health and prevent diseases but also reduce the health care costs and hospitalization rates. According to WHO guidelines breast feeding should be continued till six months for complete growth and development of the infants [9]. All participants in our study knew that exclusive breastfeeding and breastfeeding influences childhood development and cognition and also reduces the health care costs. But still they could not follow the WHO guidelines. Our results showed that their practices regarding exclusive breastfeeding were not good. Some of the mothers added other foods before six months with exclusive breastfeeding and it had negative consequences on the health of the infant. Infants suffered frequently from GI problems, chest infections and other diseases even through preparation of formula milk or by early initiation of complementary feeding. There is a requirement of strong implementation polices regarding exclusive breastfeeding by health care providers.

A study conducted in Ottawa, Canada showed that the rate of formula fed and partially breastfed infants was higher $(25.6 \%)$ while the rate of exclusively breastfed infants for four months was low (14.7\%). Children living in lower income households were less likely to be exclusive breastfed in comparison to children of mothers with higher level of education and children living in higher income household. The study showed that education influenced the practices of exclusive breastfeeding. Only a few countries met the WHO criteria the figure of Ottawa was low as compared to Austria exclusive breast feeding for six months of age reached $46 \%$ and in Sweden $42 \%$. Our study also had almost the similar findings, that is, the participants who were educated they knew well regarding exclusive breastfeeding. Some participants didn't know the importance of education. They followed their old traditions of exclusive breastfeeding by the guidance of their elders. There is a need to plan campaigns of exclusive breastfeeding in rural and urban communities to increase the level of education and awareness of mothers regarding exclusive breastfeeding and how education influences practices of mothers regarding exclusive breastfeeding.

WHO recommended that if the mother has tuberculosis, hepatitis B and C breast feeding should be continued. It has not very dangerous effects on the health of the infants [13]. It has been shown that formula milk was harmful and hazardous effects than exclusive breast feeding of HIV-1 infected mother. It appeared to be protective because in developing countries more pathogen contaminated due to unsafe water and improper disposal of human wastes [12-14]. Our study participants didn't know that if the mother has hepatitis B and C, and tuberculosis she could continue to give breastfeeding to her infant. Some of the mothers described that if mother had hepatitis B and C 
she could not give breastfeed to her infant. But this is a misconception arise here. Unfortunately, at every point there is a need to give awareness to the community regarding knowledge of exclusive breastfeeding and breastfeeding.

A study conducted in Saudi Arabia showed that 343 participants who participated in that study answered that colostrum was good for the infants. On the other hand, some considered that it was not good or even harmful to the child's health and very few didn't know the answer.

Pakistan has lowest exclusive breastfeeding rate in South Asia. Over the last seven years the exclusive breastfeeding rate in children in Pakistan has remained static. The percentage of exclusive breastfeeding has risen only very little. A study conducted in Karachi showed that antenatal average was good but knowledge about newborn care was poor. Mothers were practicing wrong practices regarding newborn care. $97 \%$ mothers started breast feeding and only $48 \%$ started within two hours of delivery. The rate of exclusive breastfeeding was found to be $26 \%$. Some mothers discarded colostrum.

If the knowledge, attitude and practices of mothers become good it can protect the infants from various diseases and also improve the immunity of the infants and reduce the burden of diseases in the country. Exclusive breast feeding is very much necessary for the baby from one day to six months. There should be no addition of other food till six months. It should be started immediately after birth. Awareness sessions should be arranged regarding exclusive breastfeeding knowledge, attitude and practices in future pregnancy to improve the health status of infants at community level. Government should take steps to improve the knowledge, attitude and practices of mothers regarding exclusive breastfeeding.

\section{CONCLUSION}

The study gave a basic level of knowledge, attitude and practices of mothers about exclusive breast feeding. Breastfeeding is a natural and beneficial source of nutrition and provides the healthiest start for an infant. In addition to the nutritional benefits, breastfeeding promotes a unique and emotional connection between mother and baby. Most of the mothers knew the advantages of breast feeding and its importance for the health of the infants. They also knew that breast feeding is important to prevent the infants from various diseases.

\section{RECOMMENDATIONS}

Based on the observations made during the study, the following are the recommendations in order to improve the nutritional status of the infants;
1. Additional research in this field needs to be undertaken because the current figures of exclusive breastfeeding in Pakistan are far below than the desired ones. Also, the prevalence of bottle feeding in infants is on a high and these issues need to be taken care of. This is only possible when additional research is carried out in this particular field. Since the present study was undertaken only in one tertiary care hospital of Islamabad, there should be more research conducted across the country in order to assess the knowledge, attitude and practices of mothers regarding exclusive breastfeeding so that appropriate interventions can then be designed.

2. Perhaps, there should be an entirely separate section of exclusive breastfeeding in the national health policy of Pakistan so that the better health of infants can be ensured.

3. A multi-sectoral approach would be needed to address the issue of exclusive breastfeeding. The government as well as the private sector need to cooperate in this regard and work on the community level to raise the awareness about this extremely important public health problem.

4. Appropriate nutrition education needs to be imparted to the mother's elderly (as well as the general population) by conducting workshops and awareness seminars and inviting mothers of infants there so that they could be made aware regarding the importance of exclusive breastfeeding for the health of their children.

\section{REFERENCES}

1. World Health Organization. (2016). World health statistics 2016: monitoring health for the SDGs sustainable development goals. World Health Organization.

2. Infant and young child feeding, Fact sheet $\mathrm{N}^{\circ} 342$, Updated February 2014, Global Strategy for Infant and Young Child Feeding.

3. Black, R. E., Victora, C. G., Walker, S. P., Bhutta, Z. A., Christian, P., De Onis, M., ... \& Uauy, R. (2013). Maternal and child undernutrition and overweight in low-income and middle-income countries. The lancet, 382(9890), 427-451.

4. Black, R. E., Allen, L. H., Bhutta, Z. A., Caulfield, L. E., De Onis, M., Ezzati, M., ... \& Maternal and Child Undernutrition Study Group. (2008). Maternal and child undernutrition: global and regional exposures and health consequences. The lancet, 371(9608), 243-260.

5. Baby Center Medical Advisory Board, Last updated: April 2015: http://www.babycenter.com/0_how-breastfeedingbenefits-you-and-your-baby_8910.bc 